\title{
Construction and validation of educational technology to prevent complications in intestinal ostomies / periestomy skin
}

\author{
Construção e validação de tecnologia educacional para prevenção de complicações em estomias \\ intestinais/pele periestomia \\ Construcción y validación de tecnología educacional para prevención de complicaciones en estomas \\ intestinales/piel periestomal
}

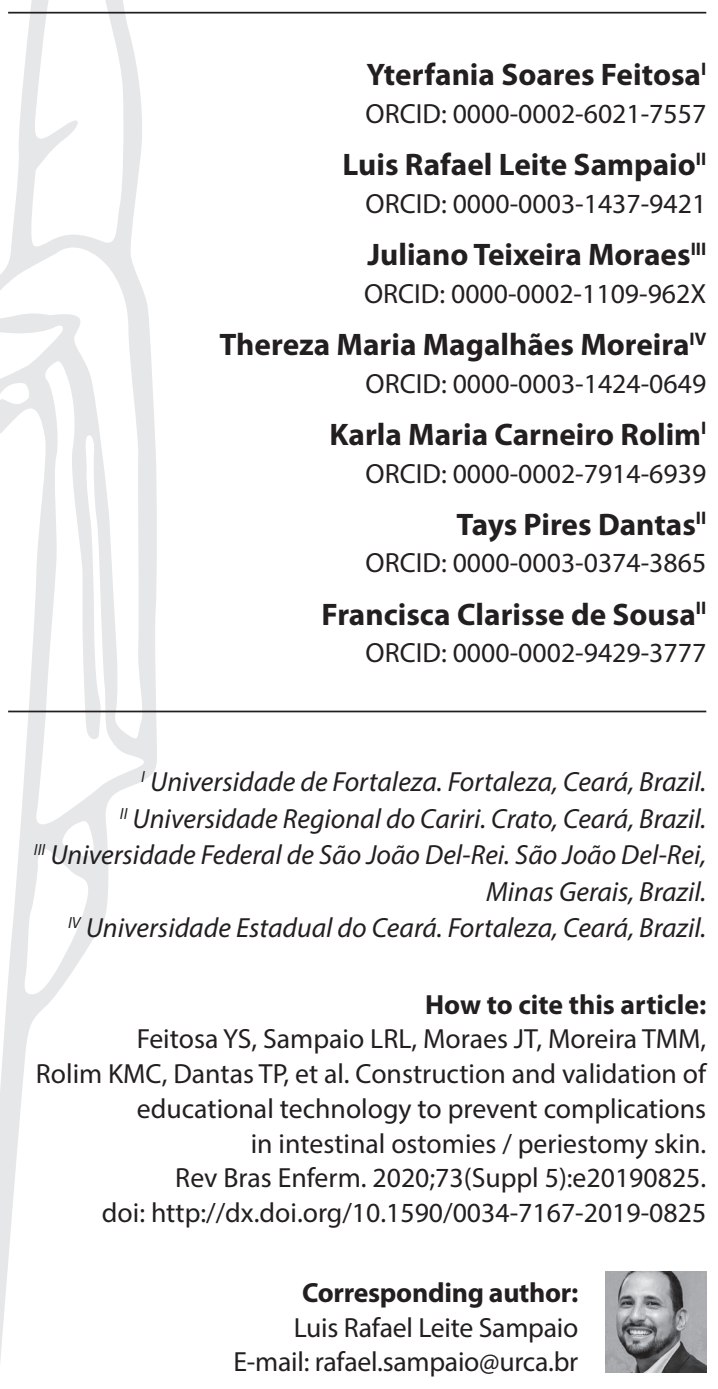

EDITOR IN CHIEF: Antonio José de Almeida Filho ASSOCIATE EDITOR: Hugo Fernandes

\begin{abstract}
Objective: To build and validate an educational booklet for preventing complications in intestinal ostomy and peristomy skin. Methods: Methodological study developed in: 1. Survey of the clinical profile of patients; 2 . Integrative review; 3 . Construction of technology; 4. Validation of educational material. The Delphi technique was used, with 18 judges with expertise in the field of stomatherapy. For data treatment, the Collective Subject Discourse (CSD), descriptive analysis, Kappa Index (K), binomial test and Content Validity Index (CVI) were used. Results: The agreement rate between judges was higher than 0.61 , for $\mathrm{K} \mathrm{p}>$ 0.05 , a proportion of $80 \%$ for the binomial test and $80 \%$ for the CVI. . The booklet showed an excellent index for K, binomial test and global content validity, becoming validated. Final considerations: The booklet was validated in appearance and content, being an instrument that can favor communication between professionals and people with ostomies. Descriptors: Prevention; Ostomies; Educational Technology; Validation Studies; Health Education.
\end{abstract}

\section{RESUMO}

Objetivo: Construir e validar cartilha educativa para prevenção de complicações em estomias intestinais e pele periestomia. Métodos: Estudo metodológico desenvolvido em: 1. Levantamento do perfil clínico dos pacientes; 2. Revisão integrativa; 3. Construção da tecnologia; 4. Validação do material educativo. Utilizou-se a técnica Delphi, com 18 juízes com expertise na área de estomaterapia. Para tratamento dos dados, empregou-se o Discurso do Sujeito Coletivo (DSC), análise descritiva, Índice Kappa (K), teste binomial e Índice de Validade de Conteúdo (IVC). Resultados: Considerou-se a taxa de concordância entre os juízes superior a 0,61 , para o $\mathrm{K} p>0,05$, proporção de $80 \%$ para o teste binomial e $80 \%$ para o IVC. A cartilha apresentou um ótimo índice para o K, teste binomial e validade de conteúdo global, tornando-se validada. Considerações finais: A cartilha foi validada em aparência e conteúdo, sendo um instrumento que pode favorecer a comunicação entre profissionais e pessoas com estomias.

Descritores: Prevenção; Estomias; Tecnologia Educativa; Estudos de Validação; Educação em Saúde.

\section{RESUMEN}

Objetivo: Construir y validar cartilla educativa para la prevención de complicaciones en estomas intestinales y piel periestomal. Métodos: Estudio metodológico desarrollado en: 1. Levantamiento del perfil clínico de los pacientes; 2 . Revisión integrativa; 3 . Construcción de la tecnología; 4. Validación del material educativo. Se utilizó la técnica Delphi, con 18 jueces con dominio en el área de estomaterapia. Para tratamiento de los datos, se empleó el Discurso del Sujeto Colectivo (DSC), análisis descriptivo, Índice Kappa (K), test binomial e Índice de Validad de Contenido (IVC). Resultados: Se consideró la tasa de concordancia entre los jueces superior a 0,61 , para el $\mathrm{K} p>0,05$, proporción de $80 \%$ para el test binomial y $80 \%$ para el IVC. La cartilla presentó un óptimo índice para el K, test binomial y validad de contenido global, volviéndose validada. Consideraciones finales: La cartilla ha sido validada en apariencia y contenido, siendo un instrumento que pode favorecer la comunicación entre profesionales y personas con estomas.

Descriptores: Prevención; Estomas; Tecnología Educativa; Estudios de Validación; Educación en Salud. 


\section{INTRODUCTION}

The use of printed educational materials has reached an increasing value with regard to increasing knowledge about education and health within the teaching-learning process ${ }^{(1-2)}$. These resources are also considered innovative means for health care, as they constitute strategies that simplify the orientation to the individual regarding the maintenance of their favorable health status, which has positive impacts on the development of their self-care ${ }^{(3-4)}$.

In addition, it is known that the use of printed educational technologies is an important means of promoting dialogue and interrelationship between the patient and the health team, since it guarantees an expanded and informative communication between all those involved, including family members of customers ${ }^{(3-4)}$.

Specifically for people with intestinal ostomy, the educational booklet can play an important role, especially in preventing complications in ostomies and skin peristomies, favoring people to recognize complications, development of attitudes, skills and providing the understanding that their own actions influence their health standard, facilitating their autonomy ${ }^{(5)}$.

Among the complications most present in people with intestinal ostomy, peristomy skin dermatitis stands out ${ }^{(6)}$. Studies indicate that there are several causes for this complication, such as: absence of demarcation in the preoperative period; inadequate cutting of the collection bag; type of collecting equipment; allergies to barrier creams and protective plaque; and in particular the lack of knowledge of the person undergoing the ostomy process ${ }^{(6-7)}$.

Thus, educational strategies that start from the surgical decision through the postoperative period to outpatient care will be strengthened with the support of the educational booklet, that is necessary to minimize complications in people with intestinal ostomies and, thus, promote empowerment of self-care ${ }^{(3-4)}$. This is because the educational booklet allows the person with an ostomy and their family to read the nursing guidelines in stomatherapy later, reinforcing the information addressed orally and serving as a guide to complement the educational process, answer questions and assist in decision making ${ }^{(5)}$.

Given the above, the interest in building and validating an educational booklet addressing strategies for preventing complications in intestinal ostomy and skin peristomy has emerged from both an epidemiological study, not yet published, which evidenced the profile of complications in intestinal ostomy and peristomy skin in the state of Ceará, as well as the authors' professional experience in caring for people with ostomies.

\section{OBJECTIVE}

Build and validate an educational booklet to prevent complications in intestinal ostomy and peristomy skin.

\section{METHODS}

\section{Ethical aspects}

The study was approved by the Research Ethics Committees of the institutions where the research was carried out, receiving favorable opinions for its execution and ensuring compliance with the recommendations of Resolution No. 466/12.

\section{Theoretical-methodological framework}

\section{Type of study}

This is a methodological and development study. Methodological research aims to structure and elaborate creative processes that aim at research tools and methods $s^{(8)}$.

This investigation was carried out in four stages, namely: 1. Survey of the clinical profile of participants with intestinal ostomy in the state of Ceará; 2. Integrative review; 3. Construction of educational technology; 4 . Validation of content and technical appearance of educational material by judges ${ }^{(9)}$.

\section{Methodological procedures, study scenario and data organization}

In the first stage, an epidemiological study was carried out between April and June 2018. The research took place through a semi-structured interview containing questions about the types of complications and the causality of complications in patients with intestinal ostomies treated in the reference cities for ostomy in the state of Ceará, Brazil.

In the second stage, an integrative review was carried out from December 2018 to January 2019, in the PUBMED database (US National Library of Medicine) and in three virtual libraries: Virtual Health Library (VHL); Scientific Electronic Library Online (SciELO) and Cochrane Library. This process took place in six stages: identification of the theme / guiding question of the research; establishment of sampling criteria for inclusion and exclusion of studies; evaluation of selected publications; evaluation of publications included in the review; categorization / interpretation of extracted information; and presentation of the knowledge review / synthesis ${ }^{(9-10)}$, in order to identify in the literature which interventions for the prevention and treatment of complications in intestinal ostomy and skin peristomy.

In the third stage, the process of building a booklet based on three aspects was implemented: language, illustration and layout / design - which are recommended for the preparation of educational materials printed in health ${ }^{(11)}$.

First, the texts were elaborated, with objective language and culturally adapted to the target audience. Then, a specialist in graphic design was consulted to make the illustrations and the layout in the programs Adobe Photoshop CS6 and Adobe Photoshop, respectively. The booklet was prepared between January and February 2019 and revised in March 2019 after validation.

In the fourth stage, the content validation of the booklet was carried out, the process of which was guided by the theoretical framework of content validity ${ }^{(8)}$. At that time, the Delphi technique was used, which consists of a systematic method of judging information, useful to obtain consensus of experts on a given topic through validations articulated in phases or cycles ${ }^{(12)}$.

The study counted on 11 researcher / teacher judges and seven technical judge / stoma assistant nurses, for validation of the booklet, which took place in February 2019. 
The search for the judges was carried out through a survey on the Lattes Platform of the CNPq portal. The search by subject (keyword: stomatherapy) was started in the simple search option, and filters were used to refine the criteria. Another strategy for searching for judges occurred through snowball sampling ${ }^{(13)}$. Thus, the judges identified by this type of sampling and who met the pre-established criteria adapted from the consulted literature ${ }^{(14)}$ were invited to participate in the study, and were asked to indicate other participants.

For the selection of judges, the expert classification system was used ${ }^{(15)}$, appropriate to this study, with selection of judges who reached a minimum score of 5 points. For the researching / teaching judges, the criteria adopted are shown in Chart 1, below.

The technical judges / assistant stomatherapist nurses were selected according to their technical knowledge proven in the monitoring of patients with intestinal ostomy, having as inclusion criteria those shown in Chart 2, below.

After applying the inclusion criteria of the judges, the invitation was sent, via electronic mail, which stated the purpose of the research. Then, according to the participants' acceptance, the Free and Informed Consent Term, the booklet and the form containing the analysis criteria for the judges were conducted via electronic mail. Their work consisted of a critical reading of the booklet to complete the evaluation form, which was composed of 18 items considering four requirements: objectives, structure, presentation and relevance.

Chart 1 - Criteria for the selection of researcher / teacher judges, Crato, Ceará, Brazil, 2019

\begin{tabular}{|l|c|}
\hline Research / teaching judges & Score \\
\hline $\begin{array}{l}\text { Be a master or doctor with scientific production in the } \\
\text { field of ostomies }\end{array}$ & 2 points/work \\
\hline $\begin{array}{l}\text { Production of educational technology in the area of } \\
\text { interest* }\end{array}$ & 1 point/work \\
\hline $\begin{array}{l}\text { Participate in research groups / projects that involve } \\
\text { the theme of the area of interest* }\end{array}$ & 1 point/work \\
\hline $\begin{array}{l}\text { To have participated in thesis, dissertation or } \\
\text { monographs for undergraduate or specialization } \\
\text { evaluations involving the theme in the area of interest* }\end{array}$ & 0,5 point/work \\
\hline $\begin{array}{l}\text { Have teaching experience in discipline in the area of } \\
\text { interest* }\end{array}$ & 1 point/work \\
\hline
\end{tabular}

Chart 2 - Criteria for the selection of stomatherapy nursing specialists, Crato, Ceará, Brazil, 2019

\begin{tabular}{|l|c|}
\hline Specialist in stomatherapy nursing & Score \\
\hline Have experience in clinical practice & 0,5 point/year \\
\hline Time of practical work with patients with ostomy & 1 point/year \\
\hline $\begin{array}{l}\text { Being a stomatherapy specialist and / or a member of } \\
\text { the Brazilian Association of Stomatherapy - SOBEST; }\end{array}$ & 1 point \\
\hline $\begin{array}{l}\text { Development of preventive and / or health promotion } \\
\text { actions aimed at people with intestinal ostomy }\end{array}$ & 0,5 point/year \\
\hline Have participated in events in the area of interest* & 0,5 point/event \\
\hline Have papers presented in the area of interest* & 0,5 point/work \\
\hline
\end{tabular}

Note: *Area of interest: Experience with patients with intestinal ostomies; Educational health technology.
For the content validity of the booklet, the Kappa Index (K) was applied in order to measure the degree of agreement and consistency between the judges. The kappa results were interpreted as follows: weak $(\leq 0)$, mild $(0.01-0.20)$, reasonable $(0.21$ $0.40)$, moderate $(0.410 .60$, substantial $(0,61-0.80)$ and almost perfect $(0.81-1.00)^{(16)}$. As an acceptance criterion, an agreement higher than 0.61 was established between the judges.

In addition, the binomial test for content validation was used. In this statistical analysis, an item is considered adequate if a certain percentage of evaluators defines $i^{(17)}$. For this, the significance level $p$ of $5 \%$ was considered to reject the null hypothesis, so that the values of $\mathrm{p}<0.05$ were statistically significant. However, it is considered the appropriate item if the test did not present statistical significance of $p>0.05$ and a proportion of $80 \%$ of experts was in agreement.

The Content Validity Index (CVI) was also used. This method uses a Likert scale with a score of 1 to 5 and is based on the responses of the judges regarding the degree of relevance of each item, classified as: 1 - Inadequate; 2 - Partially adequate; 3 - Adequate; 4 - Totally adequate; NA - Not applicable.

To evaluate the booklet, a calculation recommended by researchers in the field was used ${ }^{(8-9)}$, in which the sum of all CVIs calculated separately is divided by the number of items in the instrument.

An agreement rate between judges of $80 \%$ was considered acceptable for the assessment of clarity and objectivity and 0.80 for the assessment of relevance, considering it to be an acceptable index to verify the validity of new instruments with an assessment made by more six judges ${ }^{(18)}$. Items that obtained a lower agreement ratio were excluded or modified, according to the suggestions presented. The variables were analyzed in a descriptive manner (simple frequency and percentage).

\section{RESULTS}

The data is displayed in two distinct categories: construction of the booklet and validation of the booklet.

\section{Construction of the booklet}

Initially, data was collected to build the textual content of the booklet, with searches for recent and relevant publications on the theme being worked on and relevant to the care of ostomies. As a result, 22 publications were obtained.

The content covered was divided into nine domains:"What is an ostomy?", "What is stomatherapy?", "Demarcation", "Types of bags", "Complication", "Collection equipment exchange guidelines", "Time of use ", "Features and location of the stoma" and "Program for the Care of Ostomy Patients".

Subsequently, textual elaboration of the information contained in the booklet was initiated, in order to reach all audiences, regardless of the social class and / or educational level of the individuals. Soon after, the making of the illustrations began, which had as theme the Brazilian Northeastern Hinterland, having as the protagonist the figure of Francisco in the role of patient and Maria as a stomatherapist nurse; finally, it ended with the layout of all the content. 

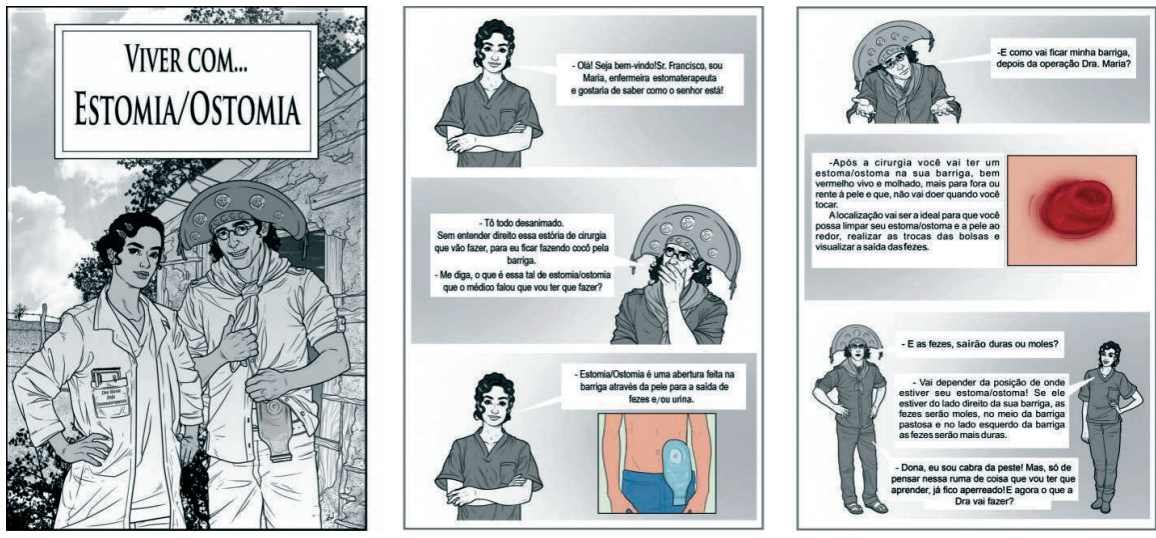

Figure 1 - Cover illustration, content and layout of the booklet "Living with ... Ostomy /Stoma", Crato, Ceará, Brazil, 2019

The booklet was reproduced on A4 paper; size A5 (closed), with coated paper on the cover and offset paper inside the booklet, consisting of 19 pages in the pre-validation phase. After completing its layout, it was sent for analysis by the judges and, in its final version, was entitled "Living with ... Ostomy / Stoma" (Figure 1).

\section{Validation of the booklet}

After the booklet construction process, it was submitted for validation. At this stage, it was evaluated by 18 expert judges on the subject, of whom 16 (88.9\%) were female; and 2 (11.1\%), male. Their age ranged from 30 to 58 years, with an average of 42 years. Of the total, five (27.8\%) had the title of doctor; nine $(50.1 \%)$, from master; and four $(22.4 \%)$ had specialist titles. Regarding the experience of validating technologies according to the proposal of this study, $16(88.9 \%)$ of the judges had expertise in the subject.
The agreement of each judge on the 18 items was calculated and then the kappa of all items was calculated, with a result of 0.84 , which means almost perfect agreement on all the items evaluated.

By the binomial test, it is observed (Table 1) that items 6 and 7 of the requirement Structure and presentation could be improved. In addition, items $1,2,5$ and 11 , of the same requirement, although they did not obtain $80 \%$ approval from the judges, remained without statistical significance in the binomial test, which represents a clear difference between their judgment in the sense to be supportive of these items.

Table 1 shows the content validity index performed in two moments by the judges. In the meantime, the booklet obtained a general agreement index of 0.78 in the first moment and 0.91 in the second moment, which can be considered valid.

\section{DISCUSSION}

The construction and validation of the educational technology "Living with ... Ostomy / Stoma" followed a methodological rigor to ensure that scientific information was accessible and easily understood by the target audience, as recommended by the literature ${ }^{(6,11,17-19)}$.

The educational booklet was validated based on the calculation of $\mathrm{K}$, binomial test and $\mathrm{CVI}$, and an agreement rate between judges greater than 0.61 for $\mathrm{K}$ was considered acceptable, $\mathrm{p}>0.05$ and an $80 \%$ proportion for the binomial test and $80 \%$ for the $\mathrm{CVI}$, obtaining a valid agreement for most of the items evaluated.

Table 1 - Distribution of the evaluation of the booklet by stomatherapy nursing experts regarding objectives, structure, presentation and relevance (n =18), Crato, Ceará, Brazil, 2019

\begin{tabular}{|c|c|c|c|}
\hline Variables & $p$ value* & CVI $1 * *$ & CVI $2^{* * *}$ \\
\hline \multicolumn{4}{|l|}{ Objectives } \\
\hline 1. Are consistent with the needs of patients with ostomies. & 0.37 & 0.77 & 0.90 \\
\hline 2. Promotes change in behavior and attitudes. & 0.41 & 0.72 & 0.90 \\
\hline 3. Can circulate in the scientific environment in the area of stomatherapy. & 0.41 & 0.72 & 0.90 \\
\hline \multicolumn{4}{|l|}{ Structure and presentation } \\
\hline 1. The educational material is suitable for guiding patients with intestinal ostomy. & $0.23^{\mathrm{a}}$ & 0.66 & 0.90 \\
\hline 2. The messages are presented in a clear and objective way. & $0.11^{\mathrm{a}}$ & 0.83 & 0.90 \\
\hline 3. The information presented is scientifically correct. & 0.37 & 0.73 & 0.95 \\
\hline 4. There is a logical sequence of the proposed content. & 0.37 & 0.83 & 0.99 \\
\hline 5. The material is appropriate to the socio-cultural level of the proposed target audience. & $0.11^{\mathrm{a}}$ & 0.5 & 0.90 \\
\hline 6. The information is well structured in terms of concordance and spelling. & $0.01^{\mathrm{a}}$ & 0.5 & 0.90 \\
\hline 7. The writing style corresponds to the level of knowledge of the target audience. & $0.01^{\mathrm{a}}$ & 0.61 & 0.90 \\
\hline 8. Information on the cover, back cover, acknowledgments and / or presentation are consistent. & 0.37 & 0.77 & 0.93 \\
\hline 9. The illustrations are expressive and sufficient. & 0.59 & 0.83 & 0.90 \\
\hline 10. The number of pages is adequate. & 0.37 & 0.61 & 0.85 \\
\hline 11. Title and topic sizes are appropriate. & $0.23^{\mathrm{a}}$ & 0.66 & 0.90 \\
\hline \multicolumn{4}{|l|}{ Relevance } \\
\hline 1. The themes portray the relevant aspects that must be reinforced. & 0.18 & 0.88 & 0.95 \\
\hline $\begin{array}{l}\text { 2. The material proposes to the patient with an ostomy's knowledge about the attitudes of preventing } \\
\text { and treating complications in ostomy and peristomy skin. }\end{array}$ & 0.06 & 0.94 & 0.90 \\
\hline $\begin{array}{l}\text { 3. The material addresses the issues necessary for prevention and treatment of complications in ostomy } \\
\text { and peristomy skin. }\end{array}$ & 0.59 & 0.77 & 0.90 \\
\hline 4. It is suitable for use by health professionals in their educational activities. & 0.59 & 0.77 & 0.95 \\
\hline
\end{tabular}


However, in addition to the objective assessment presented by the statistical tests, the subjective aspects of this process were valued; and the suggestions proposed by the judges were considered of great relevance, as it was possible to adapt the booklet to the preferences and culture of the participants, as well as to professional judgment. The adjustments made in the language, layout/design and illustration took place according to the theoretical framework adopted ${ }^{(9)}$.

In terms of language, scientific terms have been replaced or added as suggested by the judges, and some texts have been reformulated in order to better understand the target audience. For the construction of educational materials, technical and scientific information is needed that is written in a simple and clear manner, aiming to facilitate reading and interpretation ${ }^{(9,20)}$. The layout/design was readjusted in terms of organization, colors and contrasts; some illustrations were redesigned in order to better represent reality. The changes occurred according to works whose indication is that visual aids should be used both to present extensive and complex concepts in a didactic way and to assist in understanding the texts and facilitating reading, making it more attractive and creative $\mathrm{e}^{(9,21-22)}$.

\section{Study contributions}

The construction of educational technologies in different contexts and health scenarios shows that the use of $\mathrm{K}$, binomial test and CVI, with subjective evaluation by judges, enables the development of quality educational material ${ }^{(6,9,23)}$.

It is also emphasized the importance of the specialty of the judges who evaluated the booklet. The evaluation by stomatherapists with expertise in the field of ostomies shows that in fact the work is being done to meet an existing demand, valuing diverse opinions and approaches on the same topic. The construction of educational materials is also an opportunity to standardize and formalize specialized assistance to the person who will undergo ostomy, in the preoperative period ${ }^{(23)}$.

With the elaboration of quality educational materials, it is possible to carry out educational interventions based on structured knowledge and information directed to the clientele. In the context of the prevention of complications in intestinal ostomies, such interventions are necessary so that, on the one hand, positive behaviors are developed and adherence to self-care and strategies for preventing complications in the preoperative period are increased, which, on the other hand, demands greater involvement of health professionals with health education and clientele $e^{(9,23)}$.

The establishment of prevention strategies for the person with an ostomy is essential, as it is well known that the lack of experience with the ostomy after the surgery can lead to an emotional disruption, making these individuals often associate the making of an ostomy with death. Still others showed insecurities and uncertainties regarding their future with the ostomy ${ }^{(24)}$. For this, it is necessary, according to Ordinance 400/09, the role of the stoma nurse in health services in support of patients who will be submitted to the process of making the ostomy ${ }^{(25)}$.

At that moment, strategies for preventing complications in ostomy and peristomy skin are launched, such as: demarcation of the possible site of the ostomy, testing of collecting equipment, handling the patient with the devices, strengthening self-care and empowering knowledge in order to become active the person involved in the process ${ }^{(23)}$.

The validation of educational material with representatives of the target audience is a necessary procedure and provides an important gain for the researcher and the team involved. It is a moment when you realize what is really missing, what has not been understood and the distance that exists between what is written and what is understood and how it is understood ${ }^{(21)}$.

\section{Study limitations}

As a limitation of this study, one can mention the non-validation by the target audience and by a specialist in the communication area. Having completed the construction and internal validation of the booklet, the study does not end here: it is emphasized that it will undergo continuous updates through scientific progress; also, it is intended to offer it, after validation by the target audience, to the Health Secretary of the State of Ceará, for use in specialized services, as well as to conduct future research to evaluate its effectiveness in reaching the implementation of strategies to strengthen self-care for people with intestinal ostomy.

Finally, it emphasizes the need for support from government agencies for reproduction, in different media, in addition to the printed version, with a view to the dissemination and wide distribution of this material in health services.

\section{FINAL CONSIDERATIONS}

The objective of the study was achieved to describe the construction and validation of the educational booklet to prevent complications in ostomy and peristomy skin, this being the first to be developed in the state of Ceará. The booklet was validated from the point of view of language, illustration and layout / design by expert judges, and should therefore be considered for the context of educational activities as an instrument capable of favoring the strengthening of self-care for the person who will be submitted to intestinal ostomy surgery.

It is believed that the use of this material will facilitate the practice of evidence-based nursing, considering that it constitutes an illustrated technology capable of favoring the dialogue between professionals and the people who will undergo ostomy-generating surgeries. This makes it easier for patients to acquire knowledge in order to ease complications in ostomy and peristomy skin.

\section{REFERENCES}

1. Sá DLF, Pinheiro RX, Araújo MMO, Falcão PC, Chagas MX. Cuidados com o Paciente Pré-Cirúrgico de Ostomia. Rev Científ Multidiscip Núcleo Conhecimento [Internet]. 2018 [cited 2019 Sep 28];4(1):21-30. Available from: https://www.nucleodoconhecimento.com.br/saude/paciente-pre-cirurgico-de-ostomia 
2. Nunes MLG, Santos VLC de G. Instrumentos de avaliação das complicações na pele periestomia: revisão integrativa. Aquichan [Internet]. 2018 [cited 2019 Sep 28];18(4):477-91. Available from: http://aquichan.unisabana.edu.co/index.php/aquichan/article/view/9419

3. Albuquerque AFLL, Pinheiro AKB, Linhares FMP, Guedes TG. Tecnologia para o autocuidado da saúde sexual e reprodutiva de mulheres estomizadas. Rev Bras Enferm. 2016;69(6):1164-71. doi: 10.1590/0034-7167-2016-0302

4. Moreira MDJ, Moura SN, Catunda LGM, Alves BA, Vilani CGM. Construção de cartilha sobre insulinoterapia para crianças com diabetes mellitus tipo 1. Rev Bras Enferm. 2017;70 (1):7-14. doi: 10.1590/0034-7167-2016-0183

5. Instituto Nacional de Câncer José Alencar Gomes da Silva. Cuidados com a sua estomia intestinais urinárias: orientações ao usuário. 2th ed. Rio de Janeiro (RJ): Inca; 2018. 20 p.; il.

6. Diniz IV, Silva ES, Souza RN, Diniz HDA, Costa IKF. Aspectos sociodemográficos, clínicos e complicações de pessoas estomizadas por câncer Rev Saúde Ciên [Internet]. 2018 [cited 2019 Sep 28];7(2):6-18. Available from: http://www.ufcg.edu.br/revistasaudeeciencia/index.php/ RSC-UFCG/article/view/611

7. Feitosa YS, Sampaio LRL, Moreira DAA, Mendonça FAC, Viana MCA, Sacramento KPN, Silva FM, Carvalho TB, Galdino YLS. Significados atribuídos às complicações de estomia e pele periestomia em um serviço de referência na região do Cariri. Estima, Braz J Enterostomal Ther [Internet]. 2018 [cited 2019 Sep 20];16(1):1-7. doi: 10.30886/estima.v16.651_pt

8. Polit DF, Beck CT. Índice de validade de conteúdo: você tem certeza de que sabe o que está sendo relatado? crítica e recomendações. Res Enferm Saúde. 2006;29(5):489-97.

9. Benevides JL, Coutinho JFV, Pascoal LC, Joventino ES, Martins MC, Gubert FA, et al. Construção e validação de tecnologia educativa sobre cuidados com úlcera venosa. Rev Esc Enferm USP [Internet]. 2016 [cited 2019 Aug 15];50(2):309-16. Available from: http://www.scielo.br/ pdf/reeusp/v50n2/pt_0080-6234-reeusp-50-02-0309.pdf

10. Beardsworth SJ. Building Knowledge Bridges through Effective Science Communication. Chemistry. A Europ J. 2020;26(8):1-6. doi: 10.1002/ chem.201905685

11. Deatrick D, Aalberg J, Cawley J. A guide to creating and evaluating patient materials. guidelines for effective print communication [Internet] Portland: MaineHealth; 2010 [cited 2018 Nov 16]. Available from: https://mainehealth.org/-/media/community-education-program-cep/ health-literacy/mh-print-guidelines.pdf?la=en

12. Massaroli A, Martini JG, Lino MM, Spenassato D, Massaroli R. The Delphi method as a methodological framework for research in Nursing. Texto Contexto Enferm. 2017;26(4):e1110017. doi: 10.1590/0104-07072017001110017

13. Vinuto J. A amostragem em bola de neve na pesquisa qualitativa: um debate em aberto. Temáticas [Internet]. 2014 [cited 2019 Sep 20];22 (44):201-18. Available from: https://econtents.bc.unicamp.br/inpec/index.php/tematicas/article/view/10977

14. Moreira MF, Nóbrega MM, Silva MI. Comunicação escrita: contribuição para a elaboração de material educativo em saúde. Rev Bras Enferm. 2003;56(2):184-8. doi: 10.1590/S0034-71672003000200015

15. Joventino ES. Construção e validação de escala para mensurar a autoeficácia materna na prevenção da diarreia infantil. Fortaleza (CE): 2010.

16. Landis JR, Koch, GG. (1977). The Measurement of observer agreement for categorical data. Biometrics. 33(1):159-74. doi: 10.2307/2529310

17. Lopes MVO, Silva VM, Araujo TL. Validação de diagnósticos de enfermagem: desafios e alternativas. Rev Bras Enferm. 2013;66(5):649-55. doi: $10.1590 /$ S0034-71672013000500002

18. Paula FWS. Construção e validação de um gibi como tecnologia em saúde para prevenção da obesidade em adolescentes escolares [Dissertação]. Fortaleza: Universidade Estadual do Ceará; 2017. 76 p.

19. Polit DF, Beck CT. Delineamento de Pesquisa em Enfermagem. In: Polit, D.F. and Beck, C.T., Eds., Fundamentos de pesquisa em enfermagem: avaliação de evidências para prática de enfermagem. Porto Alegre: Artmed; 2011. 247-368p.

20. Moura DJ, Moura NS, Menezes LCG, Barros AA, Guedes MV. Construção de cartilha sobre insulinoterapia para crianças com diabetes mellitus tipo 1. Rev Bras Enferm. 2017;70(1):7-14. doi: 10.1590/0034-7167-2016-0183

21. Lima AC, Bezerra KC, Sousa DM, Rocha JF, Oriá MO. Construção e Validação de cartilha para prevenção da transmissão vertical do HIV. Acta Paul Enferm. 2017;30(2):181-9. doi: 10.1590/1982-0194201700028

22. Machado WCA, Pereira JS, Schoeller SD, Júlio LC, Marrtins MMFPS, Figueiredo NMA. Integralidade na rede de cuidados da pessoa com deficiência. Texto Contexto Enferm. 2018;27(3):e4480016. doi: 10.1590/0104-07072018004480016

23. Carvalho DS, Silva AGI, Ferreira SRM, Braga LC. Elaboration of an educational technology for ostomized patients: peristomal skin care. Rev Bras Enferm. 2018;72(2):427-34. doi: 10.1590/0034-7167-2016-0024

24. Mota MS, Gomes GC, Petuco VM. Repercussions in the living process of people with stomas. Texto Contexto Enferm. 2016;25(1):1-8. doi: 10.1590/0104-070720160001260014

25. Ministério da Saúde (BR). Portaria № 400, de 16 de Novembro de 2009. Brasília (DF): Ministério da Saúde; 2009. 